\title{
Time dependency of hydrogen - ion concentration and electric conductivity measurements in river water samples of Central Amazonia ${ }^{(1)}$
}

\author{
W.L.F. Brinkmann \\ A. dos Santos \\ Instituto Nacional de Pesquisas \\ da Amazônia
}

\begin{abstract}
The hypothesis was tested, whether hydrogen ion concentration and electric conductivity in river water samples of the Tertiary region of central Amazonia were subject to changes in time and due to nature of storage. Over a period of about two months only changes in $\mathrm{pH}$ and conductivity of Rio Negro water samples were found to be significant. The total deviation of both parameters in rain forest stream samples was considered negligible for at least a period of 30 days, independant of the nature of storage (laboratory or icebox). The latter results may be generalized more or less unconditionally for the entire Tertiary formations of Amazonia.
\end{abstract}

\section{INTRODUCTION}

The hydrogen-ion concentration $(\mathrm{pH})$ in natural waters is controlled by chemical reactions and equilibria among the ions in solution. As far as the water samples studied were concerned, the $\mathrm{pH}$ was primarily determined by the chemical nature of the watersheds (substrates, soils, vegetation cover, etc), the chemical reactions under way in the river basins (decomposition - and remineralization processes, release of various acids (sulfuric, organic and carbonic), biological processes (photosynthesis, respiration, etc.) and the current (mixing capacity).

Although the hydrogen - ion concentration in river waters is not a main controlling factor in fresh water ecology (Reid,
1961), it should be recognized, that several water organisms have their specific $\mathrm{pH}$ tolerance ranges (Welch, 1952).

The electric conductivity is a measure to evaluate the total amount of ionized material in water solutions. The total amount. and the composition of dissolved solids in water control up to a certain extent, the variety and abundance of aquatic organisms. Although no exact relationship exists between electric conductivity and total dissolved solids in natural waters, the parameter (electric conductivity) is often used as a first approximation to determine the influence of total dissolved solids on the aquatic environment.

Hydrogen - ion concentration and electric conductivity in water samples are liable to changes during storage between sampling and laboratory measurements, owing to reactions to suspensions, hydrolyses, oxidationreduction processes, loss of dissolved gases, etc. If samples are collected and stored with care, the early laboratory measurements are supposed to approximate field conditions. If samples reach the laboratory after a two or three months, the reliability of the data is assumed to be dependant on the delay. This hypothesis was tested for several river water samples of central Amazonia.

1) - Granted by Banco Nacional de Desenvolvimento Econômico under contract INPA/FUNTEC 89/70. This paper was originally published in Vol. 1, No 1 of this Revista. Because of omissions of lines and clauses of the text, and also because the tables and illustrations were not included in the publication of the paper, it is now republished in this issue of Revista. 
MATERIAL AND METHODS

At June 6 th, 1971 four water samples were collected at Paricatuba, the Rio Negre narrows, at about $15 \mathrm{Km}$ upstream of the city of Manaus. Water was sampled in different depths and positions of the Rio Negro cross - section, as.; midstream (surface), midstream (40 m depth), $300 \mathrm{~m}$ off right bank $(20 \mathrm{~m}$ depth) and $300 \mathrm{~m}$ off left bank $(20 \mathrm{~m}$ depth) .

At August 8 th, 1971, water samples from four rain forest streams were collected along the BR-174, the Manaus - Caracarai Road at kilometers $61,35,32$ and 27 . These streams drain watersheds of different sizes, but are undisturbed by human activity (slash and burn, cattle breeding, etc.). The areas are covered with a terra firme rain forest, a climax forest of the chapadas of the Tertiary region in central Amazonia. The forest type is closely related to heavy or extremely heavy yellow latosols. Along the river banks hydromorphic soil is common. Several small patches of tropical podzol soils occur scattered on the hill slopes. These soils are covered with "carrasco forests" or campinas.

All water samples were stored in pyrex bottles, handled with care and sent back to the laboratory within six hours.

The Rio Negro samples were stored in the laboratory. The BR-174 samples were divided. One set of samples remained under laboratory conditions, the other set of four samples was stored in an icebox.

The hydrogen - ion concentration was measured with a pH - meter, type 390 WTW, Germany. The electric conductivity was read by means of a conducitivity meter, type LBR - WTW, Germany. Hydrogen - ion concentration and electric conductivity were repeatedly measured (average of $\mathbf{5}$ subsamples) for all three sets of samples concurrently up to September 9 th, 1971.

Changes in $\mathrm{pH}$ and conductivity during the time between sampling and first laboratory measurements occured, but these inter- ferences were disregarded, because field instruments showed an instrumental error of about 5 - 10 percent in dupplicated samples.

The Rio Negro samples (midstreamsurface) and all four BR-174 samples were analyzed for various constituents of ecological interest (see Table 1).

Sulphur compounds, organics and bacterial and fungal activity were not evaluated, although they are of considerable importance for changes in $\mathrm{pH}$ and electric conductivity of the water samples.

\section{RESULTS}

For the period measurements (Rio Negro samples: June 6th. - September 15th, 1971; BR-174 samples: August 8th. - September 15th, 1971), hydrogen-ion concentration and electric conductivity data were calculated as the deviation from the initial laboratory readings $\left(0.1 \mathrm{pH}\right.$ and $0.1 \mathrm{uS}_{20}$ intervals).

I. The Rio Negro samples.

Hydrogen ion concentration and electric, conductivity data obtained, confirmed the significant fluctuations of both parameters, depending on the sampling position in the river cross-section (see Table 2; Table 3). Concerning chemical interactions in the solution, $\mathrm{pH}$ and conductivity data proved the lack of homogenity of the Rio Negro water body. Compared with other river systems in the world, the data are very low with respect to both parameters. The deviation from the first laboratory reading over the period of measurements was significant for $\mathrm{pH}$ (range : $\mathrm{pH} 0.3-\mathrm{pH} 0.7$ ) and electric conductivity (range 0.7 $\mathrm{uS}_{2_{0}}-3.8 \mathrm{uS}_{20}$ ) respectively. While the $\mathrm{pH}$ data displayed no variation from the first laboratory readings, the electric conductivity data, howewer, increased (samples 1,3 and 4) and decreased (sample 2) with time 


\begin{tabular}{|c|c|c|c|c|c|c|}
\hline & & $\begin{array}{l}\text { Rio Negro } \\
\text { (surface) }\end{array}$ & $\begin{array}{c}\text { BR-174 } \\
(\mathrm{Km} \mathrm{61)}\end{array}$ & $\begin{array}{c}\text { BR-174 } \\
(\mathrm{Km} \mathrm{35)}\end{array}$ & $\begin{array}{c}\text { BR-174 } \\
(\mathrm{Km} \mathrm{32)}\end{array}$ & $\begin{array}{c}\text { BR-174 } \\
\left(\begin{array}{ll}\mathrm{Km} & 27\end{array}\right)\end{array}$ \\
\hline $\mathrm{pH}$ & & 5.2 & 4.7 & 4.5 & 4.6 & 4.8 \\
\hline $\mathrm{uS}_{2 \mathrm{n}}$ & & 9.9 & 5.5 & 9.2 & 6.5 & 5.5 \\
\hline $\mathrm{Ca}^{++}$ & $\mathrm{ug} / 1$ & $<20.0$ & $<20.0$ & $<20.0$ & $<20.0$ & $<20.0$ \\
\hline $\mathrm{Mg}^{++}$ & $\mathrm{ug} / 1$ & $<20.0$ & $<20.0$ & $<20.0$ & $<20.0$ & $<20.0$ \\
\hline SBV & $\mathrm{mval} / 1$ & $<0.03$ & $<0.05$ & $<0.05$ & $<0.05$ & $<0.05$ \\
\hline $\mathrm{N}\left(\mathrm{NH}_{4} \stackrel{+}{)}\right.$ & $\mathrm{ug} / 1$ & 38.4 & 44.0 & 59.8 & 29.4 & 23.0 \\
\hline $\mathrm{N}\left(\mathrm{NO}_{2}\right)$ & $\mathrm{ug} / 1$ & 1.0 & 2.7 & 2.4 & 2.3 & 3.2 \\
\hline $\mathrm{N}\left(\mathrm{NO}_{3} \overline{)}\right.$ & $\mathrm{ug} / 1$ & 39.7 & 26.6 & 27.9 & 36.1 & 21.9 \\
\hline $\mathrm{N}$ (org.) & $\mathrm{ug} / 1$ & 200.0 & 495.0 & 490.5 & 359.0 & 331.5 \\
\hline $\mathrm{N}$ (total) & $\mathrm{ug} / 1$ & 238.0 & 539.3 & 550.3 & 388.4 & 354.5 \\
\hline$P$ (total) & $\mathrm{ug} / 1$ & 3.8 & .0 & .0 & .0 & .0 \\
\hline $\mathrm{Fe}$ (total) & $\mathrm{ug} / 1$ & 39.2 & 43.9 & $2: 6.2$ & 135.2 & 125.1 \\
\hline $\mathrm{Mn}$ & $\mathrm{ug} / 1$ & - & 8.7 & 8.7 & 7.7 & 8.7 \\
\hline Si (sol.) & $\mathrm{mg} / 1$ & 1.6 & 1.6 & 2.3 & 2.2 & 2.1 \\
\hline $\mathrm{Cl}^{-}$ & $\mathrm{ug} / 1$ & 448.0 & 700.0 & 700.0 & 700.0 & 700.0 \\
\hline Color & $\mathrm{mgPt} / 1$ & 69.4 & 20.8 & 55.5 & 30.8 & 28.5 \\
\hline $\mathrm{KMnO}_{4}$ & $\mathrm{mg} / 1$ & 54.9 & 13.9 & 21.5 & 20.5 & 14.0 \\
\hline $\mathrm{CO}_{2}^{(1)}$ & $\mathrm{mg} / 1$ & - & 29.7 & 25.3 & 20.6 & 24.2 \\
\hline
\end{tabular}

TABLE 1 - Chemical constituents of 1) the Rio Negro (surface) sample (June 6, 1971) and 2) the BR-174 river samples (August 8,1971$)$. (1) samples treated with $\mathrm{CHCl}_{3}(5 \mathrm{ml} / 1)$. 
II. The BR-174 samples.

For all samples, hydrogen-ion concentration and electric conductivity values we re considerably low. The conductivity, readings of samp'es BR-174 $\mathrm{Km} 61, \mathrm{Km} 32$ and $\mathrm{Km} 27$ were extremely low (see Table 2; Table 3); The deviation in $\mathrm{pH}$ from the first laboratory measurements (range : $\mathrm{pH} 0.1-\mathrm{pH}$ 0.3 ) was insignificant for all samples and independent of storage (laboratory - icebox). Electric conductivity data showed a slight deviation from the first laboratory readings (range : $0.4 \mathrm{us}_{20}$ $2.1 \mathrm{uS}_{20}$ ).

In sample BR-174 ( $\mathrm{Km} \mathrm{35)}$ the conductivity decreased with time Some differences in total deviation from the first laboratory measurements were reported for BR-174 samples ( $\mathrm{Km} \mathrm{35}$; $\mathrm{Km} \mathrm{32)}$ as far as storage (laboratory - icebox) was concerned (see Table 3 ).

\section{CONCLUSIONS}

Hydrogen - ion concentration and electric, conductivity data of all samples analyzed were extremely low, if compared with equivalent river systems in the word.

The bicarbonate - carbon dioxide system is effective in the control of the $\mathrm{pH}$ of natural waters in about the $\mathrm{pH} 4.5$ to $\mathrm{pH} 8.0$ range (Reid, 1961). Calcium and magnesium ion analyzed were below detection in all water samples (see Table 1), i.e. the solution were poorly buffered (Brinkmann and Santos, 1971).

Hidrolyses, the most important type of reaction controlling $\mathrm{pH}$ in natural waters must play a part in fixing the low $\mathrm{pH}$ as salts of iron and ammonium were present in the samples analyzed (see Table 1). These salts give an acid reaction upon the hydrogen ion concentration.

As far as Rio Negro samples were concerned, the socalled humic complex of these

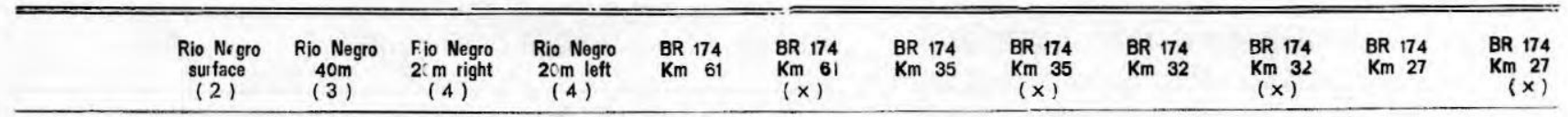

\begin{tabular}{|c|c|c|c|c|c|c|c|c|c|c|c|c|}
\hline $\begin{array}{r}6.7 .71 \\
15.7 .71 \\
23.7 .71 \\
28.7 .71\end{array}$ & $\begin{array}{r}5.2 \\
-0.2 \\
+0.1\end{array}$ & & & & & & & & & & & \\
\hline 2.8 .71 & +0.1 & & & & & & & & & & & \\
\hline 3.8.71 & +0.5 & 4.3 & 4.3 & 4.8 & & & & & & & & \\
\hline 9.8.71 & +0.5 & +0.2 & +0.2 & +0.2 & 4.7 & 4.7 & 4.5 & 4.5 & 4.6 & 4.6 & 4.8 & 4.8 \\
\hline 16.8 .71 & +0.5 & +0.4 & +0.2 & +0.2 & $(-)$ & +0.1 & $(-)$ & +0.1 & +0.1 & +0.1 & $(-)$ & $(-)$ \\
\hline 20.8 .71 & +0.4 & +0.2 & $(-)$ & +0.1 & -0.2 & $(-)$ & -0.3 & -0.2 & -0.2 & $(-)$ & -0.1 & $(-)$ \\
\hline 25.8.71 & +0.6 & +0.2 & +0.2 & +0.1 & +0.3 & +0.3 & $(-)$ & +0.1 & +0.1 & +0.1 & $(-)$ & $(-)$ \\
\hline 30.8 .71 & -0.3 & +0.2 & +0.2 & -0.3 & $(-)$ & +0.1 & +0.1 & -0.1 & +0.1 & $(-)$ & +0.2 & -0.1 \\
\hline 6.9 .71 & -0.2 & +0.7 & +0.1 & -0.3 & $(-)$ & +0.3 & +0.1 & +0.1 & $(-)$ & $(-)$ & $(-)$ & -0.2 \\
\hline 9.9 .71 & -0.2 & +0.7 & +0.1 & -0.3 & +0.1 & +0.2 & +0.1 & $(-)$ & +0.1 & $(-)$ & $(-)$ & $(-)$ \\
\hline 10.9.71 & -0.2 & +0.7 & +0.5 & +0.1 & $(-)$ & -0.1 & +0.1 & +0.1 & $(-)$ & +0.2 & -0.2 & $(-)$ \\
\hline 15.9 .71 & -0.3 & +0.7 & +0.5 & +0.2 & $(--)$ & $(-)$ & +0.1 & +0.2 & +0.1 & +0.2 & -0.1 & $(-)$ \\
\hline
\end{tabular}

(1) total

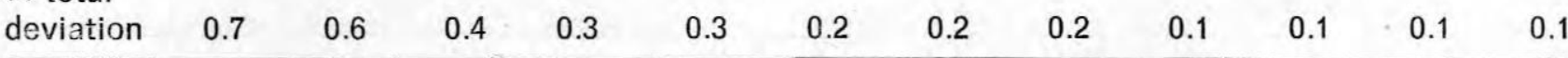

TABLE $2-\mathrm{pH}$ deviation from the initial $\mathrm{pH}$ measurements with time (in $0.1 \mathrm{pH}$ intervals).

(1) Instrumental and individual error calculated

as $\pm 0.1 \mathrm{pH}$.

(2) midstream

( 3 ) midstream, $40 \mathrm{mts}$ depth
(4) $300 \mathrm{mts}$ off banks, $20 \mathrm{mts}$ depth

(x ) samples stored in a refrigerator

(-) no deviation. 


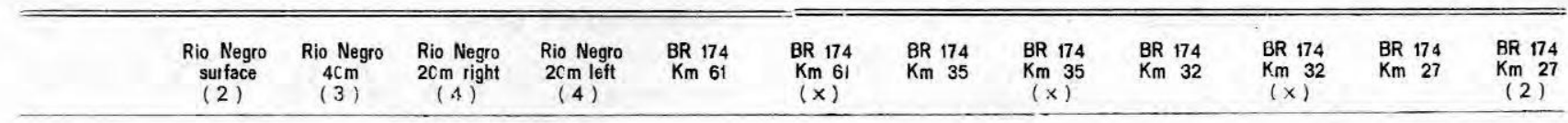

\begin{tabular}{|c|c|c|c|c|c|c|c|c|c|c|c|c|}
\hline 6.7 .71 & 9.9 & & & & & & & & & & & \\
\hline 15.7 .71 & -1.6 & & & & & & & & & & & \\
\hline 23.7.71 & -2.1 & & & & & & & & & & & \\
\hline 28.7.71 & -2.4 & & & & & & & & & & & \\
\hline 2.8 .71 & -2.4 & & & & & & & & & & & \\
\hline 3.8 .71 & -0.1 & 10.7 & 10.7 & 7.1 & & & & & & & & \\
\hline 9.8 .71 & -0.3 & -0.2 & -1.1 & +0.7 & 5.5 & 5.5 & 9.2 & 9.2 & 6.5 & 6.5 & 5.5 & 5.5 \\
\hline 16.8 .71 & -0.6 & -1.0 & -1.1 & +1.6 & $(-)$ & -0.1 & -0.2 & -0.2 & -0.1 & $(-)$ & -0.3 & +0.5 \\
\hline 20.8 .71 & -0.7 & -1.1 & -1.1 & +1.6 & -0.2 & -0.3 & -0.3 & -0.2 & -0.4 & -0.3 & -0.5 & $(-)$ \\
\hline 25.8 .71 & -0.5 & -0.8 & -1.2 & +1.6 & $(-)$ & -0.3 & -0.4 & -0.2 & -0.5 & $(-)$ & -0.4 & $(-)$ \\
\hline 30.8 .71 & -2.3 & -0.4 & -1.6 & +2.3 & -0.1 & -0.1 & -0.9 & -0.4 & -0.6 & +0.1 & -0.2 & +0.3 \\
\hline 6.9 .71 & -2.6 & -0.5 & -2.4 & +1.3 & -0.3 & -0.3 & -0.9 & -0.8 & -0.4 & +0.3 & -0.6 & -0.3 \\
\hline 9.9 .71 & -2.6 & -0.4 & -1.6 & +2.1 & -0.6 & -1.1 & -1.6 & -1.1 & -0.8 & -0.5 & -1.0 & -0.8 \\
\hline 10.9 .71 & -3.3 & -0.3 & -2.4 & +1.2 & -0.2 & -0.2 & -1.6 & -1.3 & -1.2 & -0.5 & -1.1 & +0.3 \\
\hline 15.9 .71 & -3.9 & +0.2 & -2.2 & +1.3 & -0.3 & +0.3 & -2.2 & -1.2 & -1.3 & -0.5 & -0.3 & +0.4 \\
\hline
\end{tabular}

(1) total

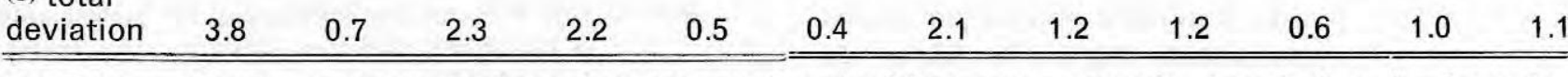

TABLE 3 - Electric conductivity deviation from the initıal conductivity measurements with time (in 0.1 uS 20 intervals)

(1) Instrumental and individual error calculated

as $\pm 0.1 \mathrm{uS}_{20}$.

(2) midstream

(3) midstream, $40 \mathrm{mts}$ depth

(4) $300 \mathrm{mts}$ off banks, $20 \mathrm{mts}$ depth

(x) samples stored in a refrigerator.

(-) no deviation.

waters may have a control function on $\mathrm{pH}$, but the reactions are no understood yet (see Table 1).

According to Schmidt (1968) total carbon dioxide in Rio Negro waters was in about the $5 \mathrm{mg} / \mathrm{l}$ range. If compared with free carbon dioxide data obtained for the BR-174 samples (see Table 1), the gas must have a profound effect on the $\mathrm{pH}$ of the rain forest stream waters. The high free carbon dioxide content of natural waters of the Tertiary regions of Amazon were also confirmed by other authors (Fittkau, 1964; Sioli, 1957).

As shown in Table 2, the fluctuations of hydrogen - ion concentration in Rio Negro samples with time were significant, while the BR-174 samples were mainly stable, i.e. at least the storage of samples over a period of 30 days was feasible as far as $\mathrm{pH}$ was concerned.

The electric conductivity data of the Rio Negro samples displayed significant variations with regard to sampling position in the river cross - section as well as in total deviation from the first laboratory measurements (see Table 3). It must be understood, that surface samples are not representative for the entire body of river water. As all water samples analyzed (Rio Negro, BR-174 samples), were extremely low in conductivity (ordinary singledistiled water used in the laboratory has a conductivity of 1 to $4 \mathrm{uS}_{20}$ ), only the Rio Negro samples (midstream surface, $300 \mathrm{~m}$ off right and left bank, $20 \mathrm{~m}$ depth) and the BR-174 sample ( $\mathrm{Km}$ 35) showed a significant change with time ( $10-30$ percent). As conductivity data were extremely low, the storage of water samples is practical at least for a period of $\mathbf{3 0}$ days. No significant differences were found between samples stored either in the laboratory or the icebox. As similar conductivity data were reported for other Tertiary regions of Amazonia (Fittkau, 1964; Sioli, 1957; Gessner, 1960), the results obtained may be generalized for the entire Tertiary formations of Amazonia. 


\section{RESUMO}

Algumas vêzes não é possível analisar no próprio local amostras d'água com relação aos valores de $\mathrm{pH}$ e condutibilidade elétrica, havendo por isso necessidade de posteriores determinações no laboratório.

Foram investigadas as possíveis variações em uma série de 4 amostras colhidas em diversas profundidades no Rio Negro, bem como uma série de 4 amosiras de diferentes igarapés da mata tropical úmida zo longo da rodovia BR-174, sendo obtidos os seguintes resultados após um período de armazenamento :

a) As variações verificadas nas amostras do Rio Negro foram significantes em relação ao período de depósito das mesmas (dois meses);

b) As amostras dos igarapés mantiveram se mais ou menos estáveis durante 30 dias. De acôrdo com os resultados obtidos por outros autores para outras regióes terciárias da Amazônia, os valores analíticos mostram a possibilidade de serem elas analisadas depois de um mês desde a data da coleta;

c) A natureza da conservação das amostras no laboratório (normal e refrigerador) não mostram variações significativas.

\section{BIBLIOGRAPHY CITED}

BrinkmanN, W. L. F. \& SANTos, A. DOS

1971 - Natural waters in Amazônia. V. Soluble magnesium properties. Turrialba, 24:95-101.

s/d - Natural waters in Amazônia. VI. Soluble calcium properties. (submetted for publication in Turrialba).

Fittikau, E. J.

1964 - Remark on limnology of central Amazon rain forest streams. Vehr. Int. Varein. Limnol., XV : 1092-96.

GESSNER, F.

1960 - Limnologische Untersuchungen am Zusammenfluss des Rio Negro und des Amazonas (Solimões). Int. Rev. ges. Hydrob., 45(1):55-79.

REID, G. K.

$1961-$ Ecology of Inland waters and Estuaries. New York, Reinhold Pub. corp.; London, Chapman and Hall, Ltd. 375 p.

Sснм:DT, G. W.

1968 - Zum Problem der Bestimmung der Kohlensaure in kalkarmen tropischen Wassern. Amazoniana. $1(4): 322-26$.

SIOLI, $\mathrm{H}$.

1957 - Valores de pH de águas amazônicas. Bol. Mus. Pa. Emílio Goeldi. Sér. Geologia, 1:1-37

WeLCH, P. S.

1952 - Limnology. New York-London, McGraw Hill book Comp. inc. $538 \mathrm{p}$. 